\title{
Additions and corrections to the Finnish flora of Myxomycetes
}

\author{
MARJA HÄRKÖNEN
}

\begin{abstract}
HÄRKÖNEN, M. 1979: Additions and corrections to the Finnish flora of Myxomycetes. - Karstenia 19: 1-7.

Finnish records are given for 22 species of Myxomycetes. The following 17 are new to Finland: Badhamia lilacina (Fr.) Rost., Comatricha alta Preuss, Cribraria rufa (Roth) Rost., Diderma effusum (Schw.) Morgan, D. montanum (Meyl.) Meyl., D. niveum (Rost.) Macbr., Didymium anellus Morgan, Enteridium splendens (Morgan) Macbr. var. juranum (Meyl.) Härkönen, Fuligo cinerea (Schw.) Morgan, Lamproderma maculatum Kow., L. sauteri Rost., L. scintillans (Berk. \& Br.) Morgan, Physarum lateritium (Berk. \& Rav.) Morgan, Stemonitis herbatica Peck, S. virginiensis Rex, Stemonitopsis dictyospora (Čelak.)Nann.-Brem., Symphytocarpus amaurochaetoides Nann.-Brem. The following five have not been reported earlier from Fennoscandia: Comatricha alta, Lamproderma maculatum, Physarum lateritium, Stemonitis virginiensis, Stemonitopsis dictyospora.

Didymium obducens Karst. is shown to be an earlier name for D. fulvum Sturgis. Enteridium splendens (Morgan) Macbr. var. juranum (Meyl.) Härkönen n. comb. is introduced as a valid name for Reticularia jurana Meyl. The report of the occurrence of Comatricha irregularis Rex in Finland is shown to have been based on a wrong determination.
\end{abstract}

Marja Härkönen, Department of Botany, University of Helsinki, Unioninkatu 44, SF00170 Helsinki 17, Finland

In the following list information is given about 22 taxa of Myxomycetes. Seventeen of them are new to Finland. The list is based on material in the Finnish herbaria H, HFR, KUO, OULU and TUR. The descriptions given below are based on my own observations and measurements. If not otherwise announced the distribution notes are based on Martin \& Alexopoulos (1969) and earlier Scandinavian records on Bjørnekaer \& Klinge (1963), Blytt (1892), Eliasson (1975), Eliasson \& Strid (1976), Eliasson \& Sunhede (1972), Härkönen (1974, 1977, 1978), Karlsen (1934, 1943), Lister (1911), Santesson (1964). The colour code numbers refer to Maerz \& Paul (1950).

\section{Badhamia foliicola A. Lister}

U: Nurmijärvi, VII.1972 Koponen (H). Helsinki, VII.1974 Koponen (H). Tuusula, IX.1976 M.H. $884(\mathrm{H})$. EK: Miehikkälä, VII.1976 Fagerström (H).-Reported from Europe, North America, Australia, Angola (Almeida 1974) and Japan (Emoto 1977). Known from Denmark and Sweden. No voucher specimen has been traced for the earlier, uncertain report from Finland (Hintikka 1920).

All the specimens represent the typical sessile form growing in crowded groups on living herbs and mosses. Spores brown, evenly warted, 9-10.7-12 $\mu \mathrm{m}$ in diam.

\section{Badhamia lilacina (Fr.) Rost.}

V: Kemiö, on Sphagnum and grasses, VIII.1972 Wikström $5014(\mathrm{H})$. - Reported from Europe and the U.S.A. Known from Denmark and Sweden. New to Finland.

Sporangia crowded, globose, sessile, $0.4-0.5 \mathrm{~mm}$ in diam. Peridium thin, opaque, slightly rough, calcareous, appearing single, pale lilac-brown (47 C 1). Capillitium of white badhamioid lime nodules, confluent in the centre and forming there pseudocolumella. Spores black in mass, dark brown in transmitted light, with rough warts and ridges, $12-13-14 \mu \mathrm{m}$ in diam.

Martin \& Alexopoulos (1969) mention the crustose porcelain-like outer peridium as a distinguishing feature of this species. The present specimen, however, has a thin peridium and it is difficult to discern two layers. Fries (1829), in the description of Physarum lilacinum, does not mention that the peridium is double. Rostafinski (1875, in describing 
the new combination $B$. lilacina), emphasizes the thick calcareous crust on the peridium, but also mentions a specimen without any lime on the peridium. The type specimen (Sweden: Femsjö, Herb. E. Fries), UPS, clearly has a double peridium. In other respects the present specimen corresponds to it well.

\section{Comatricha alta Preuss \\ (C. nigra (Pers.) Schroet. var. alta (Preuss) G. Lister)}

U: Piikkiö, on moist sawdust, VI.1967 Oittinen (H). Reported from Germany (Preuss 1851), the British Isles, the Netherlands (Nannenga-Bremekamp 1974), Poland (Krzemieniewska 1960), Switzerland, New Zealand and South Africa (Lister 1925). New to Finland.

Sporangia gregarious, $4-7 \mathrm{~mm}$ tall. Hypothallus scanty, brown. Stalk and columella black, hair-like. Capillitium attached only at the base of columella, the upper part of columella standing as a naked spike. Capillitium a tangle of brown, long flexuous threads, which branch off sparingly and have expanded tips especially at base of sporangium. Spores brown in mass, light greyish brown in transmitted light, minutely warted, $8-8.1-9 \mu \mathrm{m}$ in diam.

C. alta was described briefly by Preuss (1851). Lister (1925) treated it as a variety of $C$. nigra. Krzemieniewska (1960) and Nannenga-Bremekamp (1974) recognize it as a good species. The present specimen fits well the thorough description and figures of Nannenga-Bremekamp.

\section{Cribraria purpurea Schrad.}

EH: Tammela, Mustiala, V.1897 Karsten (H). Distributed in Europe, the U.S.A., Japan and South America (Farr 1976b). Reported from Sweden and Norway. The only earlier report from Finland (Hintikka 1920) might refer to this specimen, although Liro was mentioned as the collector.

Sporangia gregarious, $1.5-2.8 \mathrm{~mm}$ high, $0.5-1$ $\mathrm{mm}$ in diam., globose, reddish purple $(55 \mathrm{H} 8)$. Stalk concolorous, furrowed. Cup well developed, occupying about $1 / 3$ of the head of sporangium and marked by concentric plications, margin irregularly toothed. Nodes irregular, flat, angular. Dictydine granules $1.5-3 \mu \mathrm{m}$ in diam. Spores hyaline in transmitted light, minutely warted, the warts forming lax incomplete reticulation, $5-5.5-6 \mu \mathrm{m}$ in diam.

This well preserved specimen was found among the unidentified material in $\mathrm{H}$.
Cribraria rufa (Roth) Rost.

U: Vantaa, decaying wood, X.1923 Hintikka (H). Sipoo, decaying wood, IX.1972 Wikström $5010(\mathrm{H})$. - Widely distributed in Europe, North America and Japan. Reported from Denmark, Sweden and Norway. New to Finland.

Sporangia gregarious, about $1.7 \mathrm{~mm}$ high, $0.8-1$ $\mathrm{mm}$ in diam., subglobose, orange (12 D 11), stalk black, about half the total height. Cup about one third of the head of sporangium. The net widely meshed, the nodes not expanded or thickened. Spores hyaline in transmitted light with many small and some large scattered warts and weak lines (as figured by Nannenga-Bremekamp 1964), $6-6.9-8 \mu \mathrm{m}$ in diam.

\section{Cribraria vulgaris Schrad.}

V: Merimasku, VI.1860 (two specimens) Karsten (H). U: Tuusula, VII.1961 Hintikka (HFR). Kirkkonummi, VII.1976 M.H. 1301 (H). EH: Tammela, Mustiala, IX.1867 Karsten (H). St: Yläne, VII., VIII.1950 Kallio (TUR). Viljakkala, VIII.1977 M.H. 1020 (H). PS: Joroinen, VII., VIII.1914 Hintikka (H). Widely distributed, but the confusion with $C$. aurantiaca Schrad. makes the distribution data unreliable (Martin \& Alexopoulos 1969).

Sporangia gregarious, $0.9-2 \mathrm{~mm}$ high, $0.3-0.6$ $\mathrm{mm}$ in diam., yellowish brown. Hypothallus inconspicuous. Stalk dark, furrowed, $2-3$ times the height of sporangium. Cup well developed, occupying about $1 / 3$ of the head of sporangium, delicately striate by bands of granules or almost smooth, margin irregularly toothed. The net widely meshed, nodes pale or dark, broad, flat, angular, branched. Dictydine granules $1-2 \mu \mathrm{m}$ in diam. Spores hyaline in transmitted light, minutely spinulose having some large spinules, 5-6.9-7.5 $\mu \mathrm{m}$ in diam.

Cribraria vulgaris Schrad. and C. aurantiaca Schrad. have been combined in several treatments (see Martin \& Alexopoulos 1969), also in Finland (Hintikka 1920, Härkönen 1974). NannengaBremekamp (1964) pointed out a number of ways to distinguish the two species. The Finnish material has now been examined according to her treatment. The most distinctive features determining them all as $C$. vulgaris are: nodes relatively flat, broad, much branched; margin of cup irregular; spores minutely spinulose having $4-6$ large spinules on the circumfere. The lax reticulation formed of rows of spines was recognizable only in parts of the specimens. The spores had no brilliantly refracting inclusions typical to $C$. aurantiaca, and in $5 \% \mathrm{KOH}$ solution they got a greyish-purple tint. 


\section{Diderma effusum (Schw.) Morgan}

U: Espoo, at ground on leaves and twigs of Betula, VIII.1974 M.H. 23 (H). Ks: Kuusamo, on litter, VIII.1978 M.H. $1365(\mathrm{H})$ - Cosmopolitan. Found from Denmark, Norway and Sweden. New to Finland.

Plasmodiocarps very flat, about $0.5-1.5 \mathrm{~mm} \times$ up to $7 \mathrm{~mm}$ in diam. and partially fused. Peridium double, the outer white, smooth, calcareous, the inner wall membranous, grey. Columella represented by a thickened ochraceous base. Capillitium delicate, colourless. Spores dark brown in mass, light greyish brown by transmitted light, minutely warted, $7-7.9-9.5 \mu \mathrm{m}$ in diam.

\section{Diderma hemisphaericum (Bull.) Hornem.}

(Chondrioderma michelii (Libert) Rost.)

U: Espoo, on Sambucus racemosa, X.1974 Korhonen (H). - Cosmopolitan. The species is reported from Finland (Karsten 1879), but no representative herbarium material was found.

Sporangia gregarious, discoid, depressed above, umbilicate below, $1.3-1.5 \mathrm{~mm}$ in diam. Outer peridium white, fragile, inner membranous, thin, slightly iridescent. Stalk thick, white, furrowed, up to $0.5 \mathrm{~mm}$ high. Columella broad, fleshy, brown. Capillitium delicate, hyaline. Spores brown in mass, light brown by transmitted light, very finely warted, $7.5-8-8.5 \mu \mathrm{m}$ in diam.

\section{Diderma montanum (Meyl.) Meyl.}

Ks: Kuusamo, on decaying wood of Pinus sylvestris, VIII.1978 M.H. 1405 (H). - Known from Europe, North America, Japan (Emoto 1977) and South America (Farr 1976). Reported from Norway. New to Finland.

Sporangia gregarious, stalked, subglobose, flattened beneath, $0.5-1 \mathrm{~mm}$ in diam. Outer peridium chalky, pearl grey, smooth; inner peridium membranous, reddish brown. Stalk stout, short, orange-brown. Columella globose, orange-brown. Capillitium purplish at base, hyaline towards the extremities. Spores nearly black in mass, pale purplish grey in transmitted light, minutely spinulose, $10-10.2-11 \mu \mathrm{m}$ in diam.

\section{Diderma niveum (Rost.) Macbr.}

EK: Virolahti, on decaying sprouts of Pteridium, V.1971 Rintanen (OULU). - PP: Muhos, on litter, IX.1975 Ohenoja (OULU). - Distributed in Europe and North America. Reported also from Mexico (Braun \& Keller
1976), South America (Farr 1976b) and Japan (Emoto 1977). Known from Denmark, Norway and Sweden. New to Finland.

Sporangia crowded, sessile, spherical to ovoid, partially mutually depressed, $0.5-1.5 \mathrm{~mm}$ in diam., greyish white, the last-mentioned specimen having also plasmodiocarps. Peridium double, outer chalky, egg-shell-like, inner membranous, thin, weakly iridescent, grey. Hypothallus white, abundant. Columella large, hemispherical, ochraceous. Capillitium of two types: dark, uneven, nodulose, and weak, thin, hyaline. Spores nearly black in mass, dark violet-brown by transmitted light, warted, $11-11.9-12.5 \mu \mathrm{m}$ in diam.

The specimen from Muhos resembles $D$. alpinum Meyl., which according to Kowalski (1975) is said to usually produce plasmodiocarps, whereas $D$. niveum always has sporangia. When sporangiate, the sporangia of $D$. alpinum should however be less than $1 \mathrm{~mm}$ in diam. The sporangia of the specimens vary from $0.5-1.5 \mathrm{~mm}$. The spores of the two specimens are quite similar. The Muhos specimen obviously represents a case where it is impossible to draw a dividing line between the two species, as stated by Farr (1976b) who added D. alpinum to the list of synonyms for $D$. niveum.

\section{Didymium anellus Morgan}

EH: Nokia, on Secale cereale, VII.1923 Heikinheimo (H). Lammi, on stump of Picea abies, IX.1976 M.H. 894 (H). Reported from the Netherlands (Nannenga-Bremekamp 1974), England, Portugal (Almeida 1976), North America, Mexico (Braun \& Keller 1976), South America (Farr 1976b), Ceylon, India, the Philippines and Japan (Emoto 1977). Known from Sweden. New to Finland.

Sporangia pulvinate, $0.3-0.6 \times 0.3-2 \mathrm{~mm}$ in diam. Hypothallus inconspicuous. Peridium membranous, purplish brown, sprinkled with a thin layer of white, stellate lime crystals. No columella. Capillitium rather abundant, light brown, slender. Spores sepia brown in mass, light violaceous brown by transmitted light, minutely warted, in former specimen $8.5-9.9-10.5 \mu \mathrm{m}$, in the latter $6-6.8-7.5 \mu \mathrm{m}$ in diam.

Didymium obducens Karst., Not. Sällsk. Fauna Flora Fennica Förhandl. 9 (n.s. 6): 356. 1868.

(D. crustaceum Fr. var. obducens (Karst.) Karst. , Bidrag Känned. Finl. Nat. Folk 31: 115. 1879. Type: Finland. Tavastia australis: Tammela, Mustiala, Myllyperä, at base of Alnus incana, X.1866 P.A.Karsten 2035 (H). - D. fulvum Sturgis, 

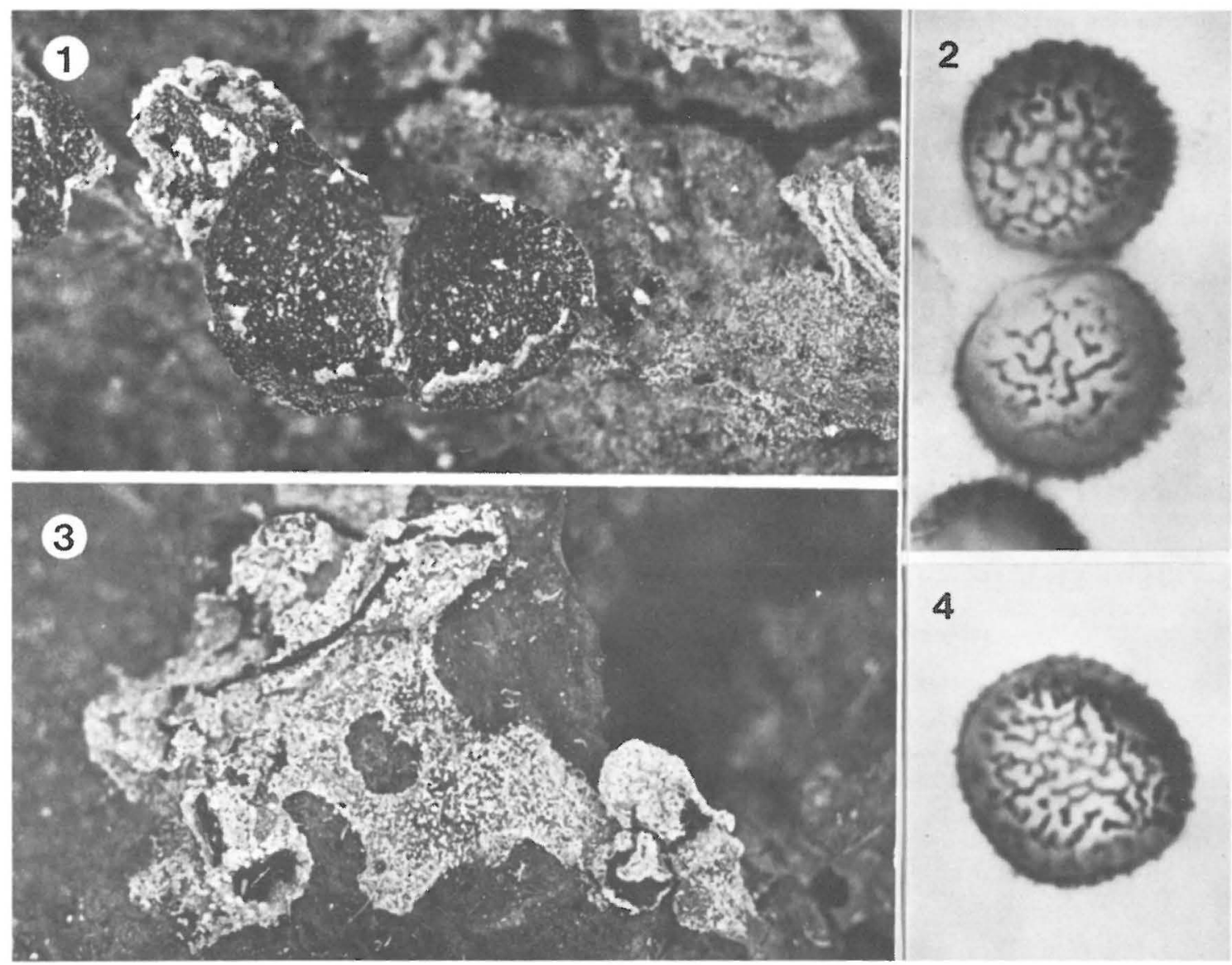

Figs. 1-4. Didymium obducens. -1 : Discoid sporangia and some hypothallus, $\times 18$ (Karsten, typus). -2 : Spores of the same (compound photograph with two focal planes), $\times 2000$. -3 : Hypothallus and sporangia, $\times 18$ (Sturgis typus ' $D$. fulvum'). - 4: A spore of the same (compound photograph), $\times 2000$. Photo Mauri Korhonen.

Mycologia 9: 327. 1917. Type: U.S.A. Colorado Mountain Valley, VIII.1913 Sturgis (NY 11338).)

Sporangia gregarious, indistinctly formed, partially confluent, discoid, concave beneath, $0.5-2$ $\mathrm{mm}$ broad, sessile or having a thick, furrowed, amorphous stalk (Fig. 1). Peridium thin, membranous, grey, slightly iridescent and having a thick, partially crustose cover of large, white to pale yellow, lime crystals. Hypothallus thick, rugose, orange-ochre (11 F- H, 3-5), having large crystalline and partially amorphous lime crystals which continue in the stalks and partially on the peridial crust and also form a thick, concave columella-like base of the sporangia. Capillitium abundant, delicate, undulating, light brown. Spores dark brown, nearly black in mass, dark brown in transmitted light, coarsely warted, the warts partially in rows forming ridges in some areas and leaving other areas almost smooth (Fig. 2), 10-11.4-13 $\mu \mathrm{m}$ in diam.

D. obducens was first described as a species by Karsten (1868). Later, however, Karsten (1879) treated it as a variety of $D$. crustaceum and so it was cited in Berlese (1888). Martin \& Alexopoulos (1969), referring to Berlese, supposed that the taxon was described only as a variety and stated that it seems to fall within the limits of variation of $D$. crustaceum.

For comparison, holotype of Didymium crustaceum Fr. (Russia, Petropoli, coll. Weinmann, det. E. Fries, UPS) was examined. The sporangia are heaped, globose to confluent - deformed and thus different from those of $D$. obducens. The yellowish limy hypothallus looks much the same as that of $D$. 
obducens. The spores of the specimen are $10-11.3-12 \mu \mathrm{m}$ in diam. and warted, but the warts are not arranged to form ridges and pale areas. $D$. obducens and $D$. crustaceum are apparently not conspecific though closely related.

According to the key in Martin \& Alexopoulos (1969), Karsten's specimen would key to D. fulvum Sturgis. The type specimen really proved to be identical with $D$. obducens. It fits well the description given above on $D$. obducens. In the specimen that I examined (Fig. 3), there were sporangia up to two $\mathrm{mm}$ broad and spores are slightly smaller $(10-11.9-13 \mu \mathrm{m})$ than given in the description of $D$. fulvum, 12.5-14.5 $\mu \mathrm{m}$ (Sturgis 1917), and have identical decorations (Fig. 4).

Sturgis (1917) concludes that $D$. fulvum stands by itself in the genus Didymium, but with decided leanings toward Lepidoderma and even Mucilago. In my opinion it is undoubtedly close to $D$. crustaceum.

As Didymium fulvum the species has been reported from Colorado and West Pakistan (Martin \& Alexopoulos 1969), and Japan (Emoto 1977).

Enteridium splendens (Morgan) Macbr. var. juranum (Meyl.) Härkönen n. comb.

(Reticularia jurana Meyl., Bull. Soc. Vaud. Sci. Nat. 44: 297. 1908. - $R$. lycoperdon Bull. var. jurana (Meyl.) G. Lister. $-R$. splendens Morgan var. jurana (Meyl.) Kow.)

St: Viljakkala, on fresh stump of Pinus sylvestris, VIII.1975 M.H. $717(\mathrm{H})$. - PP: Muhos, on fresh stump of Picea abies, V.1976 Ohenoja (Oulu). - Reported from Switzerland, the Netherlands, Great Britain, Ireland, Sweden and the U.S.A. New to Finland.

Aethalia small, $0.7-20 \mathrm{~mm}$ in diam., having firm, yellowish grey-brown cortex. Pseudocapillitium consists of a rather flaccid network of membranes at base and threads at top. Spores pale brown in mass, pale yellow in transmitted light, finely reticulate with a paler faintly warted area of dehiscence, $6-6.8-8$ $\mu \mathrm{m}$ in diam.

Lister (1925) treated this taxon as a variety of Reticularia lycoperdon. Nannenga-Bremekamp (1958) recognized it as a species, and so did Martin \& Alexopoulos (1969). Kowalski (1975) agreed that the species is distinct from $R$. lycoperdon, but found it to be very similar to $R$. splendens, differing from it only by the type of pseudocapillitium, and so included it in $R$. splendens as a variety. Farr (1976a) pointed out that the generic name Reticularia Bull. is a later homonym of the lichen genus Reticularia Baumg. and must be replaced with Enteridium Ehrenb. So the valid name for the taxon is proposed to be Enteridium splendens var. juranum.

\section{Fuligo cinerea (Schw.) Morgan}

PP: Haukipudas, on boards of Pinus, VI.1969 Ulvinen (OULU). - Cosmopolitan. New to Finland.

Aethalia flat, greyish white, $1-1.5 \mathrm{~cm}$ in diam. Spores black in mass, dark violet-brown, spinulose, some having a paler area, slightly elliptical, $10-11.2-13 \times 12-12.8-14 \mu \mathrm{m}$ in diam.

\section{Lamproderma maculatum Kow.}

PP: Muhos, on Alnus leaves and grasses, c. $60 \mathrm{~m} \mathrm{s.m.,}$ V.1970 Ulvinen (OULU). - Known from California and Washington (Kowalski 1970), and Austria (Döbbeler \& Remler 1976). New to Fennoscandia.

Sporangia gregarious, from nearly stalkless to having a stalk about the height of sporangium, $0.5-1$ $\mathrm{mm}$ in diam. Peridium fragile, bluish silvery grey and having dark depressions. Hypothallus large, discoid, brown. Columella reddish brown, attaining about half the height of sporangium. Capillitium dense, reddish brown, becoming colourless at the extremities. Spores black in mass, purple-brown by transmitted light, very finely spinulose, lighter on one side, $11-11.7-12 \mu \mathrm{m}$ in diam.

According to Kowalski (1970), the species is montane in distribution. He has found it only at high elevations near the melting snow in late spring and early summer (announced in litt.). The present specimen grew in lowlands of the middle boreal vegetation zone, but characteristically it was found in the spring on a $\mathrm{N}$ slope, where snow stays longer.

\section{Lamproderma sauteri Rost.}

PS: Kuopio, Alnus stand, c. 120 m s.m., VI. 1974 Heikkilä (KUO). - Distributed in the mountains of western North America and Europe (Kowalski 1970). Reported from Norway and Sweden. New to Finland.

Sporangia gregarious, shortly stipitate, 0.9-1.2 $\mathrm{mm}$ in diam. Peridium brownish at base, silvery, iridescent towards apex. Hypothallus thin, discoid. Columella about half the height of sporangium, slightly tapering. Capillitium dense, brown except the colourless extremities. Spores black in mass, lilacbrown in transmitted light, densely and finely spinulose with lighter and smoother areas, $12-13-14 \mu \mathrm{m}$ in diam.

According to Kowalski (in litt.) the specimen is 